\title{
Transformation of Saccharopolyspora spinosa protoplasts with plasmid DNA modified in vitro to avoid host restriction
}

\author{
Patti Matsushima and Richard H. Baltz \\ Author for correspondence: Richard H. Baltz. Tel: +1 317276 5179. Fax: +1 3172769086.
}

Lilly Research Laboratories, Eli Lilly and Company, Indianapolis, Indiana 46285 , USA

\begin{abstract}
Saccharopolyspora spinosa protoplasts were not transformable by several different streptomycete plasmids, and S. spinosa was not a host for plaque formation by the Saccharopolyspora bacteriophages $\phi$ SE6, $\phi$ SE45, $\phi$ SE57, $\phi$ SE60, $\phi$ SE69 or HP10. Extracts of S. spinosa contained DNA-modifying activities that blocked cleavage of plasmid DNA by Nael and Sall, and partially blocked cleavage by Ncol. Plasmid pOJ434, a derivative of the $S$. spinosa plasmid pSAS1, was modified in vitro by incubation with an extract of S. spinosa to circumvent restriction. Under optimal conditions, S. spinosa protoplasts were transformed to apramycin resistance by modified pOJ434 at frequencies of about $10^{4}$ per $\mu \mathrm{g}$ of DNA. Transformants contained pOJ434 primarily integrated in the chromosome.
\end{abstract}

Keywords: Saccharopolyspora spinosa, protoplasts, transformation, bacteriophages

\section{INTRODUCTION}

Saccharopolyspora spinosa was isolated from soil in a defunct sugar-mill rum still in the Virgin Islands (Mertz \& Yao, 1990). S. spinosa produces a novel insecticidal macrolide, A83543 (Kirst $e$ t al., 1991). We are interested in exploring the structural organization and regulation of A83543 biosynthetic genes, and are developing methods to introduce DNA into $S$. spinosa. S. spinosa appears to express restriction endonucleases that block transformation by plasmid DNA and block plaque formation by Saccharopolyspora bacteriophages. In this report, we describe the development of a protoplast transformation system that uses host DNA modification activity in cell extracts to circumvent restriction by in vitro modification of plasmid DNA.

\section{METHODS}

Strains, plasmids and bacteriophages. S. spinosa ATCC 49460 (Mertz \& Yao, 1990) was the host for some transformation and bacteriophage plaque-formation studies. S. spinosa PM89 is a novobiocin-treated derivative of ATCC 49460 lacking the plasmid pSAS1 (P. Matsushima \& R. H. Baltz, unpublished). Saccharopolyspora hirsuta A70162 (NRRL 12045), Saccharopolyspora sp. A51741 and Saccharopolyspora sp. A51735 (Stanzak et al., 1990) were hosts for preparing bacteriophage lysates as described by Cox \& Baltz (1984), Escherichia coli DH5 $\alpha$ (Sambrook et al., 1989) was used for the preparation and isolation of plasmids bifunctional for E. coli and actinomycetes. Streptomyces griseofuscus (Cox \& Baltz, 1984) was used to propagate plasmid pI J702. The Saccharopolyspora bacteriophages used were $\phi \mathrm{SE} 6, \phi \mathrm{SE} 45, \phi \mathrm{SE} 57, \phi \mathrm{SE} 60, \phi \mathrm{SE} 69$ (Grund \& Hutchinson, 1987) and HP10 (P. Matsushima \& R. H. Baltz, unpublished). The plasmids used in transformation and DNA modification studies were pIJ702 (Katz et al., 1983), pKC505 (Richardson et al., 1987), pOJ160 (cited in Matsushima \& Baltz, 1989), pKC796 (Kuhstoss et al., 1991), pI J4210 (Lydiate et al., 1987), pCZA168 (Solenberg \& Baltz, 1991) and pOJ434, a $6.5 \mathrm{~kb}$ vector derived from the $S$. spinosa plasmid pSAS1 that contains pUC12 for replication in E. coli and an apramycin resistance gene $\left(A \mathrm{~m}^{\mathrm{R}}\right)$ for selection in actinomycetes and $E$. coli (M. Bierman \& B. Schoner, unpublished).

Media and culture conditions. E. coli $\mathrm{DH} 5 \alpha$ was grown in TY broth (Rao et al., 1987) or TY broth plus $100 \mu \mathrm{g} \mathrm{Am} \mathrm{ml}^{-1}$ (obtained from K. Merkel, Eli Lilly) to maintain plasmid DNA. The actinomycete strains were grown in TS broth and fragmented by ultrasonic vibration (Baltz, 1978). Protoplast regeneration was carried out on modified R2 medium (Baltz, 1978), modified R2M medium (Matsushima \& Baltz, 1988), R2LE medium (Matsushima \& Baltz, 1989), R2T20 medium (Yamamoto et al., 1986) or R6 medium (Illing et al., 1989). S. spinosa was grown in TS broth (Baltz, 1978) to prepare cell-free extracts for DNA modification experiments. TS agar (Baltz \& Stonesifer, 1985) or R2LE agar supplemented with different antibiotics was used to determine the levels of antibiotic resistance expressed by S. spinosa. Bacteriophages were grown and titrated on Saccharopolyspora spp. or Actinoplanes missouriensis mycelial fragments on NC agar (Cox \& Baltz, 1984). P medium was as described by Hopwood et al. (1985).

Protoplast formation and transformation. Protoplasts of $S$. spinosa were prepared by growing cells in TS broth plus $0.3 \%$ glycine or in R6 broth plus $0.3 \%$ glycine for different times, then incubating cells in P medium with $10 \mathrm{mg}^{\prime}$ ysozyme $\mathrm{ml}^{-1}$ for $\sim 4$ h at $23^{\circ} \mathrm{C}$ (Baltz, 1978). The frequency of non-protoplasted 
cells was determined by plating dilutions of the protoplast preparations on TS agar (Matsushima \& Baltz, 1985). Typical protoplast preparations contained non-protoplasted cells at frequencies of $10^{-7}-10^{-6}$. The transformation procedures evaluated included those developed for Streptomyces spp. (Hopwood et al., 1985; Matsushima \& Baltz, 1985), Amycolatopsis orientalis (Matsushima et al., 1987b), Micromonospora rosaria (Matsushima \& Baltz, 1988) or Saccharopolyspora erythraea (Yamamoto et al., 1986). The final procedure for transformation of S. spinosa PM89 by pOJ434 was as follows. Cells were grown in R6 broth plus $0.3 \%$ glycine for $48 \mathrm{~h}$ to an $\mathrm{OD}_{600}$ of about 2 . Cells were washed and resuspended in $\mathrm{P}$ medium, then converted to protoplasts as described above. One microlitre $2 \mathrm{M} \mathrm{NaCl}$ was mixed with $6 \mu \mathrm{l}$ $\mathrm{P}$ medium and $1 \mu \mathrm{l} \mathrm{DNA}$. Undiluted protoplasts in $\mathrm{P}$ medium $(200 \mu \mathrm{l})$ and 30 or $40 \%$ PEG 6000 in P medium $(500 \mu \mathrm{l})$ were added to the DNA solution and mixed. The mixture was diluted and added in $4 \mathrm{ml}$ of modified R2 soft agar (Baltz, 1978) to bottom agar containing about $30 \mathrm{ml} \mathrm{R} 6$ medium, dehydrated as described (Matsushima \& Baltz, 1985). After 16-24 h incubation at $29^{\circ} \mathrm{C}$, the regenerating protoplasts were overlaid with $4 \mathrm{ml}$ modified R2 soft agar containing Am to give a final concentration of $50 \mu \mathrm{g} \mathrm{ml}^{-1}$. The plates were further incubated for 7-10 d, then $\mathrm{Am}^{\mathbf{R}}$ colonies were counted. Transformants were confirmed by Southern hybridizations with pOJ434.

Molecular techniques. General methods for manipulations of DNA were as described by Hopwood et al. (1985) and Sambrook et al. (1989). Southern hybridizations were carried out as described by Solenberg \& Burgett (1989). Restriction endonucleases were obtained from New England Biolabs, Bethesda Research Labs, Boehringer Mannheim Biochemicals, Amersham, United States Biochemical or Promega, and were used according to the specifications of the manufacturers.

In vitro modification of DNA. $S$. spinosa was grown in TS broth plus $0.3 \%$ glycine or R6 broth plus $0.3 \%$ glycine for $4-72 \mathrm{~h}$ (Baltz, 1978). Cells from $450 \mathrm{ml}$ culture were washed in chilled PENP buffer $(10 \mathrm{mM}$ potassium phosphate, $10 \mathrm{mM}$ EDTA, $50 \mathrm{mM} \mathrm{NaCl}$ and $0 \cdot 2 \mathrm{mM}$ PMSF, $\mathrm{pH} 7 \cdot 0$ ), then resuspended in the same buffer plus $10 \mathrm{mg}$ lysozyme $\mathrm{ml}^{-1}$ to a final volume of $\sim 10 \mathrm{ml}$. The cells were chilled in an ice bath for $10 \mathrm{~min}$, then passed through a chilled French press $[1$ in $(25.4 \mathrm{~mm})$ piston; 20000 p.s.i. (138 MPa) at high ratio]; the extract was collected in a chilled tube. Cell debris was pelleted by centrifugation in the cold. The extract was decanted and each $3 \mathrm{ml}$ of extract was mixed with $3 \mathrm{ml}$ glycerol and $0.6 \mathrm{ml} \mathrm{BSA}\left(1 \mathrm{mg} \mathrm{ml}^{-1}\right)$, then stored at $-20^{\circ} \mathrm{C}$.

The DNA modification assay included the following: 50 $100 \mu \mathrm{TNE}$ buffer $[50 \mathrm{mM}$ Tris $(\mathrm{pH} \mathrm{7.5}), \quad 50 \mathrm{mM} \mathrm{NaCl}$, $10 \mathrm{mM}$ EDTA $] ; 80 \mu \mathrm{M} S$-adenosylmethionine; $100 \mu \mathrm{g} \mathrm{BSA}$ $\mathrm{ml}^{-1} ; 25 \mu \mathrm{l}$ extract; and $0 \cdot 5-1 \cdot 0 \mu \mathrm{l}$ DNA (L. Sznyter \& $\mathrm{J}$. Brooks, personal communication). The mixture was incubated at $30^{\circ} \mathrm{C}$ for $2-16 \mathrm{~h}$, then extracted with phenol. The DNA was precipitated with ethanol, resuspended in TE buffer, and stored at $-20^{\circ} \mathrm{C}$.

\section{RESULTS AND DISCUSSION}

\section{Protoplast formation and regeneration}

A prerequisite for transformation of protoplasts was to identify conditions for efficient formation of protoplasts and regeneration of cells from protoplasts. S. spinosa mycelia, grown for $48 \mathrm{~h}$ in TS broth plus $0.3 \%$ glycine or K6 broth plus $0.3 \%$ glycine, were readily converted to protoplasts in $\mathrm{P}$ medium after incubation with $10 \mathrm{mg}$ lysozyme $\mathrm{ml}^{-1}$ for about $4 \mathrm{~h}$ at $23^{\circ} \mathrm{C}$. Protoplast re- generation was tested on several different media developed for regeneration of cells from protoplasts of Streptomyces, Amycolatopsis, Micromonospora or Saccharopolyspora spp. S. spinosa protoplasts regenerated poorly on modified R2, R2LE and R2M (i.e. $1-6 \%$ regeneration), and did not regenerate on R2T20 $\left(<10^{-6}\right.$ per protoplast), a medium developed for $S$. erythraea plasmid transformation (Yamamoto et al., 1986). S. spinosa protoplasts regenerated efficiently $(\sim 70 \%)$ on $\mathrm{R} 6$, a medium developed for Streptomyces clavuligerus protoplast transformation (Illing et al., 1989).

\section{Antibiotic resistance expressed in S. spinosa}

S. spinosa mycelial fragments formed colonies at high efficiency (e.o.p. $>0 \cdot 1$ ) on $100 \mu \mathrm{g}$ spectinomycin $\mathrm{ml}^{-1}$, $200 \mu \mathrm{g}$ hygromycin $\mathrm{B} \mathrm{ml} \mathrm{m}^{-1}$ and $50 \mu \mathrm{g}$ neomycin $\mathrm{ml}^{-1}$. S. spinosa formed colonies at an e.o.p. of $<10^{-7}$ on R2LE medium plus $25 \mu \mathrm{g} \mathrm{Am} \mathrm{m}{ }^{-1}, 50 \mu \mathrm{g}$ streptomycin $\mathrm{ml}^{-1}$ or $1 \mu \mathrm{g}$ thiostrepton $\mathrm{ml}^{-1}$. S. spinosa cells grown in TS broth plus $0 \cdot 1 \mu \mathrm{g} \mathrm{Am} \mathrm{ml}{ }^{-1}$ for $2 \mathrm{~h}$ plated at an e.o.p. of $\sim 10^{-5}$ on R2LE plus $25 \mu \mathrm{g} \mathrm{Am} \mathrm{ml}{ }^{-1}$, suggesting that $S$. spinosa may express an inducible low-level resistance to Am. However, cells grown in the presence of $0.1 \mu \mathrm{g} \mathrm{Am} \mathrm{ml}^{-1}$ formed colonies at efficiencies $<2 \times 10^{-8}$ on R2LE plus $50 \mu \mathrm{g} \mathrm{Am} \mathrm{ml}^{-1}$. Thus, $50 \mu \mathrm{g} \mathrm{Am} \mathrm{ml}^{-1}$ was chosen to select transformants with plasmids encoding $A m^{R}$.

\section{Attempts to demonstrate transformation with streptomycete plasmids}

We attempted to transform $S$. spinosa protoplasts with pIJ702, pOJ160, and pKC505, using methods described for Streptomyces or Saccharopolyspora transformations (Hopwood et al., 1985; Matsushima \& Baltz, 1985; Yamamoto et al., 1986), with R6 as the regeneration medium. Many parameters known to influence protoplast transformation frequencies were varied, including: the cell growth temperature; the culture density; the temperature for protoplast formation; the temperature for cell regeneration; the concentrations of DNA and protoplasts; and the source, $M_{\mathrm{r}}$ and concentration of PEG used to induce DNA uptake. None of the conditions tested yielded $\mathrm{Am}^{\mathrm{R}}$ or $\mathrm{Ts}^{\mathrm{R}}$ transformants. The lack of transformation suggested that the plasmids did not replicate, the resistance genes did not express, the plasmids were restricted, or a combination of problems existed.

\section{Attempts to demonstrate plaque formation with Saccharopolyspora bacteriophages}

In streptomycetes, the expression of restriction is reflected in the blockage of plaque-formation by several different bacteriophages (Cox \& Baltz, 1984; Matsushima \& Baltz, 1989). Non-restricting streptomycetes are permissive for plaque-formation by many broad-host-range streptomycete bacteriophages (Cox \& Baltz, 1984; Matsushima et al., 1987). To further probe if $S$. spinosa expressed restriction, we attempted to demonstrate plaqueformation by several different Saccharopolyspora bacteriophages. $\phi \mathrm{SE} 6, \phi \mathrm{SE} 45, \phi \mathrm{SE} 57, \phi \mathrm{SE} 60$ and $\phi \mathrm{SE} 69$ lysates prepared on $S$. erythraea did not form plaques on $S$. spinosa. 
All but $\phi \mathrm{SE} 60$ were shown previously to form plaques on different $S$. erytbraea strains and on S. hirsuta NRRL B-5792, the type strain for the genus Saccharopolyspora (Grund \& Hutchinson, 1987). $\phi$ SE6 and $\phi$ SE69 also formed plaques on four other erythromycin-producing strains related to S. erythraea (Stanzak et al., 1990). Since these bacteriophages formed plaques on several different Saccharopolyspora strains, the failure to form plaques on S. spinosa may be due to restriction.

We recently isolated a temperate bacteriophage from $S$. birsuta A58143 (ATCC 20501) designated as HP10. HP10 formed plaques on S. birsuta A55301 (ATCC 27875), S. birsuta A70162 (NRRL 12045), S. birsuta A58143, S. erytbraea C233 (NRRL 2338), Saccharopolyspora spp, strains A 37609, A51735, A51740, A51741, A51742, A51744 and A57583, and on Actinoplanes missouriensis A4696.8 (P. Matsushima \& R. H. Baltz, unpublished). Thus, HP10 appeared to have a broad host specificity for Saccharopolyspora species. We prepared HP10 lysates on four Saccharopolyspora strains that appeared to express different restriction and modification of HP10, including $S$. erythraea C233, S. birsuta A70162 and Saccharopolyspora spp. strains A51741 and A51735 (P. Matsushima \& R. H. Baltz, unpublished), but none of the lysates was able to form plaques on S. spinosa. However, each phage preparation lysed $S$. spinosa at high multiplicities of infection. Furthermore, an HP10 lysate prepared on S. erytbraea was shown to attach to $S$. spinosa in NC broth (Cox \& Baltz, 1984 ) based upon a 1000 -fold reduction in plaque-forming units after $6 \mathrm{~h}$ incubation at $32{ }^{\circ} \mathrm{C}$. The combined results suggest that HP10 can attach to $S$. spinosa and cause lysisfrom-without. We have also screened over 100 soil and fodder samples by enrichment procedures used to isolate streptomycete phages (Cox \& Baltz, 1984); none have yielded bacteriophages that form plaques on $S$. spinosa. The combined bacteriophage enrichment and host range studies suggest that $S$. spinosa may express potent restriction systems that block bacteriophage replication.

\section{Evidence for DNA modification in S. spinosa}

Total DNA isolated from $S$. spinosa was incubated with different restriction endonucleases and analysed by agarose gel electrophoresis. S. spinosa DNA was cleaved by the following enzymes: RsaI, HaeIII, HhaI, HpaII, AluI, Sau3AI, MboI, Bst YI, MflI, ApaLI, PstI, BclI, PvuII, NlaIII, XhoII, SacI, SacII, XhoI, SphI, StuI, NruI and ScaI. S. spinosa DNA was not cleaved by NaeI, NcoI, SalI or $D p n \mathrm{I}$. The lack of cleavage by $D p n \mathrm{I}$ was consistent with cleavage by $M b o \mathrm{I}$ and Sau3AI, indicating that $S$. spinosa does not express $M b o \mathrm{I}$ restriction/modification. The lack of cleavage by the other three enzymes suggested that $S$. spinosa DNA may be modified at these cleavage sites. This is supported by the observation that $S$. spinosa DNA cloned in E. coli was cleavable by NaeI, NcoI and SalI (R. N. Rao, M. Bierman, M. Basinski \& B. Schoner, personal communication). Extracts of $S$. spinosa also contain restriction endonuclease activity that cleaves $\mathrm{NcoI}$ sites (J. Brooks, personal communication), confirming that $S$. spinosa expresses isoschizomers for $N c o$ I restriction and modification. The modification data for SalI and NaeI restriction also suggest that corresponding isoschizomers for Sall and NaeI restriction endonucleases may be expressed in S. spinosa.

We isolated DNA from purified HP10 phage particles prepared on the four Saccharopolyspora strains discussed above (i.e. S. erythraea C233, S. birsuta A70162 and Saccharopolyspora spp. strains A51741 and A51735) and analysed the DNA for cleavage by NaeI, Ncol and Sall. The DNA from all four strains was cleaved by SalI and NcoI. HP10 DNAs from lysates prepared on A70162, A 51735 and A51741 were not cleaved by NaeI, but HP10 from C233 was partially cleaved by NaeI (P. Matsushima \& R. H. Baltz, unpublished). These results indicate that NaeI modification, and presumably restriction, may be common in Saccharopolyspora spp., but that modification of Nae I sites in HP10 was not sufficient to allow HP10 to form plaques on $S$. spinosa. The lack of modification of SalI and NooI sites in HP10 DNA by any of the Saccharopolyspora strains was consistent with the notion that $S$. spinosa may express $S a I I, N c o I$, and possibly other restriction systems at levels that effectively block HP10 plaque formation.

\section{Transformation of S. spinosa with pOJ434 modified in vitro}

S. spinosa contains a plasmid pSAS1 that exists in both integrated and autonomous forms (M. Howell \& R. N. Rao, unpublished). The native pSAS1 plasmid isolated from S. spinosa was shown to transform protoplasts of a S. spinosa strain cured of pSAS1, as measured by pock formation (Hopwood et al., 1985) and Southern hybridization (M. Howell \& R. N. Rao, unpublished), using R6 medium for optimum cell regeneration as described above. pOJ434, a derivative of pSAS1 (see Methods), contains two sites for NaeI, but no sites for NcoI or Sall. We attempted to transform $S$. spinosa protoplasts with pOJ434 prepared from E. coli without success. In an attempt to circumvent the apparent restriction barrier in $S$. spinosa, we prepared extracts of $S$. spinosa containing DNA-modifying activities, and incubated the extracts with pOJ434 prior to introducing the DNA into protoplasts. The DNA modification experiments were carried out under conditions designed to minimize restriction endonuclease activity (in a buffer containing EDTA and no $\mathrm{Mg}^{2+}$; see Methods). S. spinosa was grown in TS broth plus $0 \cdot 3 \%$ glycine for $4-72 \mathrm{~h}$ and extracts were assayed for DNA-modification activities using pIJ702 (five Sall, four NaeI and two NcoI sites), pKC796 (three SalI, and no NaeI or NcoI sites), pI J4210 (four Sall, six or seven NaeI and two NcoI sites), and pCZA168 (two Sall, three NaeI and one $\mathrm{NcoI}$ sites). [The numbers of sites were estimated by agarose gel electrophoresis $(0.8 \%)$; small bands $(<0.5 \mathrm{~kb})$ may not have been detected.] Extracts prepared from 24 or $48 \mathrm{~h}$ cultures gave good protection against cleavage by $\operatorname{Sal}(\sim 75-100 \%)$; extracts from 24 , 48 or $72 \mathrm{~h}$ cultures gave fair protection $(\sim 50-75 \%)$ for $\mathrm{Nae}$; and extracts from 4,6 or $8 \mathrm{~h}$ cultures gave the best protection for $\mathrm{NcoI}(\sim 50 \%)$. No modification was observed in controls lacking the methyl donor $S$-adenosylmethionine, but substantial cleavage of HP10 
was observed with extracts containing $10 \mathrm{mM} \mathrm{Mg}^{2+}$ and no EDTA.

To maximize the modification of pOJ434 for NaeI, and possibly other restriction systems, we mixed $S$. spinosa extracts from 4 and $24 \mathrm{~h}$ cultures, and incubated the mixture with pOJ434. The treated and untreated pOJ434 preparations $(2.5 \mu \mathrm{g}$ each) were mixed with protoplasts prepared from $S$. spinosa PM89 (lacking pSAS1) grown for $48 \mathrm{~h}$ in R6 plus $0.3 \%$ glycine medium, and the mixture was treated with $30 \%$ PEG 6000 . The protoplasts were plated on R6 medium and incubated at $29^{\circ} \mathrm{C}$ for $16 \mathrm{~h}$, then Am was added in modified R2 soft-agar overlays to give a final concentration of $50 \mu \mathrm{g} \mathrm{m}^{-1}$. The untreated pOJ434 gave $<0.4$ transformants per $\mu \mathrm{g}$ of DNA, whereas the pOJ434 treated with the S. spinosa mixed extracts yielded about 400 transformants per $\mu \mathrm{g}$ of DNA. The presence of pOJ434 in putative transformants was verified by Southern hybridizations : pOJ434 was inserted into the $S$. spinosa chromosome at a unique site based upon the DNA fragment size profiles after cleavage of DNA with $B a m H I$ and $E c o$ RI. However, some free plasmid was also apparent (less than one copy per chromosome). Plasmid DNA prepared from one transformant transformed S. spinosa PM89 at a frequency of about 600 transformants per $\mu \mathrm{g}$ of DNA. These experiments indicated that pOJ434 can be modified to block $S$. spinosa restriction, and that in vitro modification is nearly as efficient as in vivo modification.

We have attempted to further improve the transformation frequency with modified pOJ434 by varying several parameters known to be important for streptomycete transformations. Growth of cells in R6 medium plus $0.3 \%$ glycine for $48 \mathrm{~h}$ to an $\mathrm{OD}_{600}$ of $\sim 2$ before protoplast formation was optimal; growth for $24 \mathrm{~h}$ $\left(\mathrm{OD}_{600} \sim 0 \cdot 3\right)$ or $72 \mathrm{~h}\left(\mathrm{OD}_{600} \sim 4\right)$ yielded $10^{3}$-fold or twofold fewer transformants, respectively. The use of undiluted or 10-fold concentrated protoplasts gave similar results. PEG 6000 was superior to PEG 1000 , and treatment of protoplasts and DNA with 30 or $40 \%$ PEG 6000 gave the best results; 10 and $20 \%$ PEG 6000 gave 100 -fold and twofold fewer transformants, respectively. Addition of $0.8 \mu \mathrm{g}$ calf thymus DNA (Matsushima \& Baltz, 1985) had no effect, whereas addition of calf thymus DNA plus $1.5 \mu \mathrm{g}$ protamine sulfate (Matsushima \& Baltz, 1985) was detrimental. Addition of $0.25 \mathrm{M} \mathrm{NaCl}$ or $0.3 \mathrm{M}$ sodium acetate (Matsushima \& Baltz, 1985) gave a $50 \%$ increase in transformants. After incorporation of these minor adjustments in the transformation assay, modified pOJ434 yielded $4 \times 10^{3}$ to $1 \times 10^{4}$ transformants per $\mu \mathrm{g}$ DNA consistently. The frequency of transformants was proportional to DNA concentration between 0.5 and $2.5 \mu \mathrm{g}$ DNA ml${ }^{-1}$.

\section{Concluding remarks}

We have developed gene transfer systems for a variety of actinomycetes (Matsushima \& Baltz, 1985, 1988, 1989; Matsushima et al., 1987b; McHenney \& Baltz, 1988, 1989). S. spinosa has been the most recalcitrant strain for protoplast transformation that we have encountered. The data presented here suggest that $S$. spinosa expresses an unusually effective set of restriction systems that protect it from bacteriophages and other foreign DNA. The breakage of the restriction barrier(s) by using the host's DNAmodification enzymes has proven to be a practical solution for the introduction of pOJ434 into S. spinosa. This may be a useful approach to help open other recalcitrant microbes to molecular genetic manipulations. The recent preliminary observation of conjugal transfer of plasmid DNA from E. coli into S. spinosa (Bierman et al., 1992) is significant in light of the results presented here.

\section{ACKNOWLEDGEMENTS}

We thank M. Bierman, B. Schoner, D. Hopwood, C. R. Hutchinson and R. N. Rao for providing plasmids or bacteriophages; M. Bierman, J. Brooks, M. Howell, B. Schoner and R. N. Rao for communicating results prior to publication; L. Sznyter and J. Brooks for providing advice on the DNA modification procedure; B. Fogleman for typing the manuscript; and DowElanco Company and Eli Lilly and Company for supporting this work.

\section{REFERENCES}

Baltz, R. H. (1978). Genetic recombination in Streptomyces fradiae by protoplast fusion and cell regeneration. J Gen Microbiol 107, 93-102. Baltz, R. H. \& Stonesifer, J. (1985). Mutagenic and error-free DNA repair in Streptomyces. Mol \& Gen Genet 200, 351-355.

Bierman, M., Logan, R., O'Brien, K., Seno, E. T., Rao, R. N. \& Schoner, B. E. (1992). Plasmid cloning vectors for the conjugal transfer of DNA from Escherichia coli to Streptomyces spp. Gene 116, 43-49.

Cox, K. L. \& Baltz, R. H. (1984). Restriction of bacteriophage plaque formation in Streptomyces spp. J Bacteriol 159, 499-504.

Grund, A. D. \& Hutchinson, C. R. (1987). Bacteriophages of Saccharopolyspora erytbraea. J Bacteriol 169, 3013-3022.

Hopwood, D. A., Bibb, M. J., Chater, K. F., Kieser, T., Bruton, C. J., Kieser, H. M., Lydiate, D. J., Smith, C. P., Ward, J. M. \& Schrempf, H. (1985). Genetic Manipulations of Streptomyces: a Laboratory Manual. Norwich: The John Innes Foundation.

Illing, G. T., Normansell, I. D. \& Peberdy, J. F. (1989). Protoplast isolation and regeneration in Streptomyces clavuligerus. J Gen Microbiol 135, 2289-2297.

Katz, E., Thompson, C. J. \& Hopwood, D. A. (1983). Cloning and expression of the tyrosinase gene from Streptomyces antibioticus in Streptomyces lividans. J Gen Microbiol 129, 2703-2714.

Kirst, H. A., Michel, K. H., Martin, J. W., Creemer, L. C., Chio, E. H., Yao, R. C., Nakatsukasa, W. M., Boeck, L. D., Occolowitz, J. L., Paschal, J. W., Deeter, J. B., Jones, N. D. \& Thompson, G. D. (1991). A83543A-D, unique fermentation-derived tetracyclic macrolides. Tetrabedron Lett 32, 4839-4842.

Kuhstoss, S., Richardson, M. A. \& Rao, R. N. (1991). Plasmid cloning vectors that integrate site-specifically in Streptomyces spp. Gene 97, 143-146.

Lydiate, D. J., Henderson, D. J., Ashby, A. M. \& Hopwood, D. A. (1987). Genetics of Industrial Microorganisms, part B, pp. 49-56. Edited by M. Alacevic, D. Hranueli \& Z. Toman. Zagreb: Pliva.

Matsushima, P. \& Baltz, R. H. (1985). Efficient plasmid transformation of Streptomyces ambofaciens and Streptomyces fradiae protoplasts. J Bacteriol 163, 180-185.

Matsushima, P. \& Baltz, R. H. (1988). Genetic transformation of 
Micromonospora rosaria by the Streptomyces plasmid pI J702. I Antibiat 41, 583-585.

Matsushima, P. \& Baltz, R. H. (1989). Streptomyces lipmanii expresses two restriction systems that inhibit plasmid transformation and bacteriophage plaque formation. J Bacteriol 171, 3128-3132.

Matsushima, P., Cox, K. L. \& Baltz, R. H. (1987a). Highly transformable mutants of Streptomyces fradiae defective in several restriction systems. Mol \& Gen Genet 206, 393-400.

Matsushima, P., McHenney, M. A. \& Baltz, R. H. (1987b). Efficient transformation of Amycolatopsis orientalis (Nocardia orientalis) protoplasts by Streptomyces plasmids. J Bacteriol 169, 2298-2300.

McHenney, M. A. \& Baltz, R. H. (1988). Transduction of plasmid DNA in Streptomyces spp. and related genera by bacteriophage FP43. J Bacteriol 170, 2276-2282.

McHenney, M. A. \& Baltz, R. H. (1989). Transduction of plasmid DNA in macrolide producing streptomycetes. J Antibiot 42, $1725-1727$.

Mertz, F. P. \& Yao, R. C. (1990). Saccbaropolyspora spinosa sp. nov. isolated from soil collected in a sugar mill rum still. Int $J$ Syst Bacteriol 40, 34-39.

Rao, R. N., Richardson, M. A. \& Kuhstoss, S. (1987). Cosmid shuttle vectors for cloning and analysis of Streptomyces DNA. Methods Enzymol 153, 166-198.
Richardson, M. A., Kuhstoss, S., Solenberg, P., Schaus, N. A. \& Rao, R. N. (1987). A new shuttle cosmid vector, pKC505, for streptomycetes: its use in the cloning of three different spiramycinresistance genes from a Streptomyces ambofaciens library. Gene 61, 231-241.

Sambrook, J., Fritsch, E. F. \& Maniatis, T. (1989). Molecular Cloning: a Laboratory Manual, 2nd edn. Cold Spring Harbor, NY: Cold Spring Harbor Laboratory.

Solenberg, P. J. \& Baltz, R. H. (1991). Transposition of ' $T \mathrm{n} 5096$ and other IS493 derivatives in Streptomyces griseofuscus. J Bacteriol 173, 1096-1104.

Solenberg, P. J. \& Burgett, S. G. (1989). Method for selection of transposable DNA and characterization of a new insertion sequence, IS493, from Streptomyces lividans. J Bacteriol 171, 4807-4813.

Stanzak, R., Matsushima, P., Baltz, R. H. \& Schoner, B. E. (1990). DNA homology between Saccharopolyspora strains and other erythromycin-producing actinomycetes. J Gen Microbiol 136, 1899-1904.

Yamamoto, H., Maures, K. H. \& Hutchinson, C. R. (1986). 'Transformation of Streptomyces erytbraeus. I Antibiot 39, 1304-1313.

Received 14 June 1993; revised 23 August 1993; accepted 31 August 1993. 